\title{
BIOPSYCHOSOCIAL DETERMINANTS OF HYPERTENSION
}

\author{
Febry Istyanto'), Ambar Mudigdo²), Setyo Sri Rahardjo²) \\ 1)Masters Program in Public Health, Universitas Sebelas Maret \\ 2)Faculty of Medicine, Universitas Sebelas Maret
}

\begin{abstract}
Background: Hypertension is one of the most common and dangerous noncommunicable diseases in the world. Hypertension prevalence in Indonesia reached $34.1 \%$ and becomes the main trigger of premature death and disability. This study aimed to determine the biopsychosocial factors associated with hypertension.

Subjects and Method: This was a case control study conducted in Dr. Moewardi Hospital, Surakarta, from September to November 2018. A sample of 225 patients was selected by fixed disease sampling, consisting of 75 hypertension patients and 150 nonhypertension patients. The dependent variable was hypertension. The independent variables were anxiety, stress, sleep quality, body mass index (BMI), physical activity, vegetable and fruit consumption, coffee, and soft drink consumption. Blood pressure was measured by sphygmomanometer. BMI was measured by scale and microtoise. The other data were collected by questionnaire and analyzed by a multiple linear regression. Results: Hypertension increased with anxiety $(b=0.26 ; 95 \% \mathrm{CI}=0.01$ to $0.51 ; \mathrm{p}=$ $0.043)$, stress $(b=0.29 ; 95 \% \mathrm{CI}=0.04$ to $0.54 ; \mathrm{p}=0.025)$, poor quality of sleep $(\mathrm{b}=$ $0.46 ; 95 \% \mathrm{CI}=0.05$ to $0.88 ; \mathrm{p}=0.030), \mathrm{BMI}(\mathrm{b}=0.68 ; 95 \% \mathrm{CI}=0.04$ to $1.33 ; \mathrm{p}=0.039)$, coffee consumption $(\mathrm{b}=1.31 ; 95 \% \mathrm{CI}=0.15$ to $2.49 ; \mathrm{p}=0.028)$, and soft drink consumption $(b=0.38 ; 95 \% \mathrm{CI}=0.03$ to $0.73 ; \mathrm{p}=0.034)$. Hypertension decreased with high physical activity $(\mathrm{b}=-0.04 ; 95 \% \mathrm{CI}=-0.07$ to $-0.003 ; \mathrm{p}=0.032)$ and vegetable and fruit consumption $(\mathrm{b}=-1.14 ; 95 \% \mathrm{CI}=-2.09$ to $-0.17 ; \mathrm{p}=0.021)$.

Conclusion: Hypertension increases with anxiety, stress, poor quality of sleep, BMI, coffee consumption, and soft drink consumption. Hypertension decreases with high physical activity and vegetable and fruit consumption.
\end{abstract}

Keywords: biopsychosocial, determinants, hypertension

\section{Correspondence:}

Febry Istyanto. Masters Program in Public Health, Universitas Sebelas Maret. Jl. Ir. Sutami 36 A, Surakarta 57126, Central Java, Indonesia. Email: febryistyanto@gmail.com. Mobile: 082133452012

The 5th International Conference on Public Health Best Western Premier Hotel, Solo, Indonesia, February 13-14, 2019 | 59 https://doi.org/10.26911/theicph.2019.01.05 